\title{
Role of the Central Ascending Neurotransmitter Systems in the Psychostimulant Effects of Caffeine
}

\author{
Sergi Ferré* \\ National Institute on Drug Abuse, IRP, NIH, DHHS, Baltimore, MD, USA
}

\begin{abstract}
Caffeine is the most consumed psychoactive drug in the world. It is a non-selective adenosine receptor antagonist that in the brain targets mainly adenosine $\mathrm{A}_{1}$ and $\mathrm{A}_{2 \mathrm{~A}}$ receptors. The same as classical psychostimulants, caffeine produces motor-activating, reinforcing and arousing effects. This depends on the ability of caffeine to counteract multiple effects of adenosine in the central ascending neurotransmitter systems. Motor and reinforcing effects depend on the ability of caffeine to release pre- and postsynaptic brakes that adenosine imposes on the ascending dopaminergic system. By targeting $\mathrm{A}_{1}-\mathrm{A}_{2 \mathrm{~A}}$ receptor heteromers in striatal glutamatergic terminals and $\mathrm{A}_{1}$ receptors in striatal dopaminergic terminals (presynaptic brake), caffeine induces glutamate-dependent and glutamate-independent release of dopamine. These presynaptic effects of caffeine are potentiated by the release of the postsynaptic brake imposed by antagonistic interactions in the striatal $A_{2 A}-D_{2}$ and $A_{1}-D_{1}$ receptor heteromers. Arousing effects of caffeine depend on the blockade of multiple inhibitory mechanisms that adenosine, as an endogenous sleep-promoting substance, exerts on the multiply interconnected ascending arousal systems. Those mechanisms include a direct $\mathrm{A}_{1}$-receptor mediated modulation of the corticopetal basal forebrain system and an indirect $\mathrm{A}_{2 \mathrm{~A}}$-receptor mediated modulation of the hypothalamic histaminergic and orexinergic systems.
\end{abstract}

Keywords: Adenosine $\mathrm{A}_{1}$ receptor, adenosine $\mathrm{A}_{2 \mathrm{~A}}$ receptor, ascending arousal systems, caffeine, dopaminergic system, local modules, receptor heteromers

\section{INTRODUCTION}

In the experimental animal as well as in humans, caffeine produces the same qualitative pharmacological effects as classical psychostimulants, such as cocaine and amphetamine: an increase in motor activity, arousal and reinforcing effects [1-3]. There has been some resistance to the claim that caffeine exerts reinforcing effects, in spite of the fact that its considerable worldwide consumption provides compelling circumstantial evidence. Nevertheless, there is enough unam-

* Correspondence to: Sergi Ferré, National Institute on Drug Abuse, IRP, NIH, DHHS, 251 Bayview Blvd, Baltimore, MD 21224 , USA. Tel.: +1 443740 2647; Fax: +1 443740 2816; E-mail: sferre@ intra.nida.nih.gov. biguous experimental evidence indicating that caffeine functions as a reinforcer under certain conditions both in laboratory animals and humans [2,4]. However, it is important to point out that caffeine has a weaker reinforcing efficacy than classical psychostimulants $[2,4]$. In fact, caffeine users often fulfill the criteria for drug dependence, but not for drug abuse, established by the Diagnostic and Statistical Manual of Mental Disorders (DSM IV; 4th edition) [2]. Furthermore, in humans, caffeine produces similar subjective stimuli to classical psychostimulants [2] and, in the experimental animal, caffeine and classical psychostimulants produce similar discriminative-stimulus effects [5-7].

Caffeine is a non-selective competitive adenosine receptor antagonist and produces its psychostimulant effects by counteracting the tonic effects of endogenous 
adenosine on central adenosine receptors. This depends largely on the ability of adenosine to modulate the function of multiple central ascending neurotransmitter systems, which are involved in motor activation and reward (dopaminergic systems) and arousal (cholinergic, noradrenergic, histaminergic, orexinergic systems). Among the four cloned adenosine receptors $\left(\mathrm{A}_{1}, \mathrm{~A}_{2 \mathrm{~A}}, \mathrm{~A}_{2 B}\right.$ and $A_{3}$ receptors), $A_{1}$ and $A_{2 A}$ receptors are the ones predominantly expressed in the brain. Caffeine has similar in vitro affinities for $\mathrm{A}_{1}, \mathrm{~A}_{2 \mathrm{~A}}$ and $\mathrm{A}_{2 B}$ receptors and much lower affinity for $\mathrm{A}_{3}$ receptors [8]. $\mathrm{A}_{1}$ and $A_{2 A}$ receptors are the preferential targets for caffeine in the brain, since physiological extracellular levels of adenosine are sufficient to occupy and, therefore, stimulate $\mathrm{A}_{1}$ and $\mathrm{A}_{2 \mathrm{~A}}$ receptors. On the other hand, $\mathrm{A}_{2 B}$ receptors have a lower affinity for adenosine and are only activated by high pathological extracellular levels of adenosine $[7,8] . \mathrm{A}_{1}$ receptors are widely expressed in the brain, including the striatum, while $\mathrm{A}_{2 \mathrm{~A}}$ receptors are highly concentrated in the striatum $[8,9]$. The striatal localization of both receptors seems to underlie the motor-activating and reinforcing effects of caffeine, which depend on the adenosine-mediated modulation of the ascending dopaminergic system. On the other hand, $\mathrm{A}_{1}$ receptors localized in the basal forebrain and $\mathrm{A}_{2 \mathrm{~A}}$ receptors localized in the hypothalamus are believed to be mostly responsible for the arousing properties of caffeine, which depend on the adenosinemediated modulation of the ascending arousal systems.

\section{CAFFEINE AND THE ASCENDING DOPAMINERGIC SYSTEM}

An important amount of experimental evidence supports a key role of dopamine in the psychostimulant effects of caffeine in animals and humans. For instance, dopamine depletion or blockade of dopamine receptors significantly impairs the motor and discriminative stimulus effects of caffeine [10,11]. Most probably the same basic dopamine-mediated mechanisms are involved in the motor-activating and reinforcing effects of caffeine, as it happens with classical psychostimulants $[12,13]$. The key to understand these mechanisms of action is understanding how adenosine modulates dopaminergic neurotransmission in the brain.

\section{The striatum and the striatal spine module}

The ascending dopaminergic systems originate in the mesencephalon (substantia nigra and ventral tegmen- tal area) and innervate the striatum (caudate-putamen, nucleus acumbens and olfactory tuberculum), cortex (mostly prefrontal), amygdala, and hippocampus [14]. These systems are involved in motor activation and learning and expression of goal-directed behaviors. The striatum is the main input structure of basal ganglia and contains the highest innervation of dopamine and the highest density of dopamine receptors in the brain [14]. In the striatum, the GABAergic striatal efferent neuron, also called the medium spiny neuron (MSN), constitutes more than $95 \%$ of the striatal neuronal population [14]. There are two subtypes of MSNs, which selectively express one of two peptides, enkephalin or dynorphin. Enkephalinergic MSNs predominantly express dopamine $\mathrm{D}_{2}$ and $\mathrm{A}_{2 \mathrm{~A}}$ receptors, while dynorphinergic MSNs predominantly express dopamine $\mathrm{D}_{1}$ receptors and adenosine receptors of the $A_{1}$ subtype $[15,16]$ (Fig. 1). The MSN receives two main afferents: glutamatergic afferents from cortical, thalamic, and limbic areas and the dopaminergic afferents from the mesencephalon. Both sets of afferents converge on the dendritic spine of the GABAergic efferent neuron. Glutamatergic and dopaminergic terminals make preferential synaptic contacts with the head and the neck of the dendritic spine, respectively $[14,16]$ (Fig. 1). The dendritic spine, the glutamatergic terminal, the dopaminergic terminal and astroglial processes that wrap the glutamatergic synapse constitute the most common local module in the striatum, which we recently named striatal spine module (Fig. 1). We define "local module" as the minimal portion of one or more neurons and-or one or more glial cells that operates as an independent integrative unit [16]. The segregation of dopamine and adenosine receptors in the two subtypes of medium spiny neurons implies the existence of at least two subtypes of striatal spine module (Fig. 1).

Adenosine is a key modulator of dopaminergic and glutamatergic neurotransmission in the striatal local module. Recent studies indicate that astroglia plays a fundamental role in the formation of extracellular adenosine which can influence synaptic transmission. Astrocytes express glutamate receptors (mostly metabotropic) and ATP receptors which, when activated, induce astrocytes to release glutamate and ATP $[17,18]$. Astroglial-released ATP is then converted to adenosine in the extracellular space by means of ectonucleotidases [19]. Furthermore, there also seems to be a neurotransmitter-like formation of adenosine, a synaptic pool of adenosine. Adenosine can be produced from ATP co-released with glutamate, which 

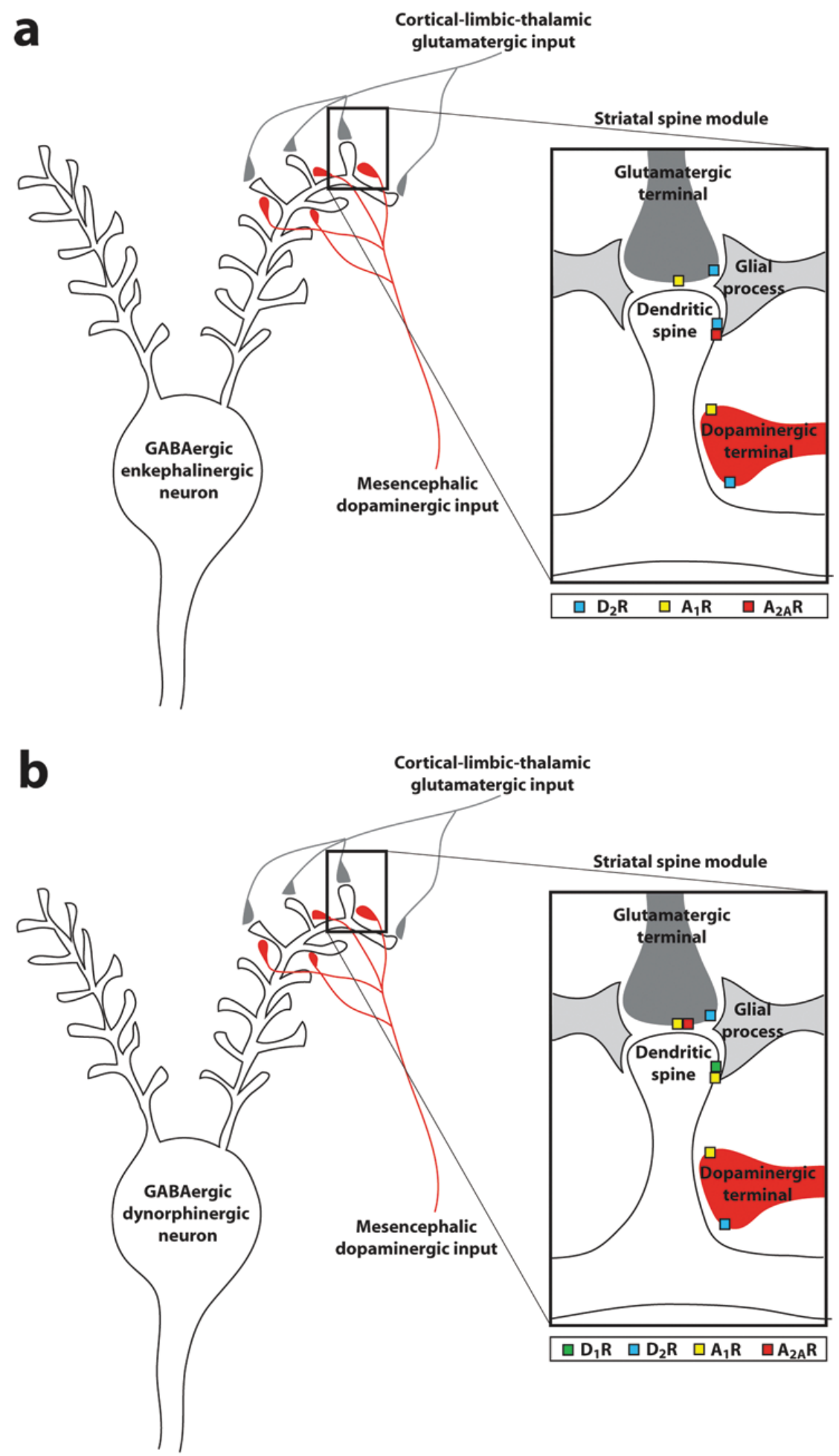

Fig. 1. Caffeine targets in the striatal spine modules of the GABAergic enkephalinergic neuron (a) and GABAergic dynorphinergic neuron (b). Adenosine $\mathrm{A}_{2 \mathrm{~A}}$-dopamine $\mathrm{D}_{2}$ receptor heteromers are localized in the dendritic spines of the GABAergic enkephalinergic neuron and adenosine $\mathrm{A}_{1}$-dopamine $\mathrm{D}_{1}$ receptor heteromers are localized in the dendritic spines of the GABAergic dynorphinergic neurons. Presynaptic $\mathrm{A}_{2 \mathrm{~A}}$ receptors form heteromers with $\mathrm{A}_{1}$ receptors and are localized in the striatal glutamatergic terminals that make contact with the dendritic spines of the GABAergic dynorphinergic neuron. $A_{1}$ receptors are also localized in a fraction of dopaminergic terminals (modified from ref. [16]). 
is also metabolized to adenosine by means of ectonucleotidases [20]. In the striatal spine module, $\mathrm{A}_{2 \mathrm{~A}}$ receptors are localized postsynaptically in the dendritic spine of enkephalinergic MSNs, colocalized with $\mathrm{D}_{2}$ receptors and presynaptically in glutamatergic terminals to the dynorphinergic MSNs [3,9,15-17,20-23] (Fig. 1). Dopamine $\mathrm{D}_{2}$ receptors are also localized in dopaminergic and glutamatergic terminals, where they do not seem to form heteromers with $\mathrm{A}_{2 \mathrm{~A}}$ receptors [24]. $A_{2 A}$ receptors are also expressed in dopaminergic and GABAergic terminals, but with lower density than postsynaptic $\mathrm{A}_{2 \mathrm{~A}}$ receptors in enkephalinergic MSN and presynaptic $\mathrm{A}_{2 \mathrm{~A}}$ receptors in glutamatergic terminals, [25]. Thus, some studies suggest the existence of functional striatal $\mathrm{A}_{2 \mathrm{~A}}$ receptors in the dopaminergic terminals, which do not directly modulate dopamine release, but that control dopamine release induced by glial cell line-derived neurotrophic factor (GDNF) [26,27]. Recent studies support the existence of $\mathrm{A}_{2 \mathrm{~A}}$ receptors in the striatal collaterals of the enkephalinergic MSNs, activation of which facilitates GABA release [28]. Less clear is the significance of some studies suggesting that activation of striatal $\mathrm{A}_{2 \mathrm{~A}}$ receptors in striatal GABA terminals inhibits GABA release [29]. Finally, functional $A_{2 A}$ receptors have also been suggested to be localized in nerve terminals from cholinergic interneurons (which should also be included in the striatal spine modules, mostly as asynaptic varicosities that release acetylcoline by volume transmission [16]) where they are co-localized with $\mathrm{A}_{1}$ receptors [30]. Presynaptically, $\mathrm{A}_{1}$ receptors are localized in glutamatergic terminals, colocalized with $\mathrm{A}_{2 \mathrm{~A}}$ receptors in those terminals which contact dynorphinergic MSNs, and in a fraction of dopaminergic nerve terminals [21,22,31]. Postsynaptically, $A_{1}$ receptors are localized in the dendritic spine of dynorphinergic MSNs, colocalized with $\mathrm{D}_{1}$ receptors $[15,20]$ (Fig. 1). In order to understand the role of adenosine in the striatum, we have to understand the role that the different adenosine receptor subtypes play in the different elements of the striatal spine module.

\section{Postsynaptic mechanisms: Adenosine-dopamine receptor heteromers}

In the striatal spine, antagonistic interactions between $A_{2 A}$ and $D_{2}$ receptors modulate the function of the enkephalinergic MSN, and antagonistic interactions between $A_{1}$ and $D_{1}$ receptors modulate the function of the dynorphinergic MSN $[15,16,20]$. This gives the explanation at the neuronal level of an important number of pharmacological findings indicating a selective modulation of $\mathrm{A}_{1}$ and $\mathrm{A}_{2} \mathrm{~A}$ receptor ligands on $D_{1}$ and $D_{2}$ receptor agonists-induced behavioral effects, respectively. Thus, $\mathrm{A}_{1}$ and $\mathrm{A}_{2 \mathrm{~A}}$ receptor agonists counteract, respectively, the motor activating effects induced by dopamine $\mathrm{D}_{1}$ and $\mathrm{D}_{2}$ receptor agonists. Similarly, $\mathrm{A}_{1}$ and $\mathrm{A}_{2 \mathrm{~A}}$ receptor antagonists potentiate, respectively, the motor activating effects induced by dopamine $\mathrm{D}_{1}$ and $\mathrm{D}_{2}$ receptor agonists [15, 16,20]. The molecular mechanisms responsible for the selective antagonistic $A_{1}-D_{1}$ and $A_{2} A-D_{2}$ receptor interactions seem to depend on allosteric interactions between adenosine and dopamine receptors forming receptor heteromers. In fact, there is compelling evidence for the existence of $A_{1}-D_{1}$ and $A_{2} A_{-} D_{2}$ receptor heteromers in artificial cell systems and in the striatum [16, $20,24,32]$. In the $A_{2 A}-D_{2}$ receptor heteromer, the stimulation of the $A_{2 A}$ receptor decreases the binding of dopamine to the $\mathrm{D}_{2}$ receptor [33]. This allosteric interaction in the $\mathrm{A}_{2 \mathrm{~A}}-\mathrm{D}_{2}$ receptor heteromer controls neuronal excitability and, consequently, neuronal firing and neurotransmitter (GABA) release by the enkephalinergic MSN [34,35]. This is related to the ability of $\mathrm{D}_{2}$ receptors to suppress $\mathrm{Ca}^{2+}$ currents through Ltype voltage-dependent calcium channels by a cAMPprotein kinase A (PKA)-independent and phospholipase C (PLC)-dependent signaling pathway [24,32]. Thus, stimulation of striatal $\mathrm{A}_{2 \mathrm{~A}}$ receptor does not produce a significant effect on its own, but it strongly counteracts the depressant effects of $\mathrm{D}_{2}$ receptor stimulation on neuronal firing and neurotransmitter release in the enkephalinergic MSN [34,35].

In addition to the allosteric interaction in the $\mathrm{A}_{2 \mathrm{~A}}$ $\mathrm{D}_{2}$ receptor heteromer, a reciprocal antagonistic interaction between $A_{2} A$ and $D_{2}$ receptors has been found at the second messenger level. In this case stimulation of $\mathrm{D}_{2}$ receptors counteracts the activation of adenylylcyclase induced by stimulation of $\mathrm{A}_{2 \mathrm{~A}}$ receptors [20,24, 32]. Stimulation of $A_{2 A}$ receptor, through its coupling to $\mathrm{G}_{\text {olf }}$ proteins, can potentially stimulate adenylylcyclase, with consequent activation of cAMP-PKA signaling pathway and induction of the expression of different genes, such as c-fos and preproenkephalin, by activating the constitutive transcription factor cAMP response element binding protein (CREB) [20,24,32]. $\mathrm{A}_{2 \mathrm{~A}}$ receptor-mediated activation of PKA can also induce phosphorylation of dopamine and cAMPregulated phosphoprotein $32 \mathrm{kDa}$ (DARPP-32) at threonine $34\left(\mathrm{Thr}_{34}\right)$ and a phosphatase 2-mediated dephosphorylation of DARPP-32 at Thr75 [20,24,32]. Furthermore, $\mathrm{A}_{2 \mathrm{~A}}$ receptor-mediated activation of PKA 
can phosphorylate AMPA glutamate receptors, which play a crucial role in the initial plastic changes of glutamatergic synapses, which includes synaptic recruitment of AMPA receptors [20,24,32]. However, under basal conditions, stimulation of $\mathrm{A}_{2 \mathrm{~A}}$ receptors can poorly activate cAMP-PKA signaling and increase gene expression, due to a strong tonic inhibitory effect of endogenous dopamine and $\mathrm{D}_{2}$ receptor stimulation on adenylyl-cyclase $[20,24,32] . \mathrm{D}_{2}$ receptor blockade is then necessary to reveal the effects of a tonic activation by endogenous adenosine on $\mathrm{A}_{2 \mathrm{~A}}$ receptormediated PKA activation [20,24,32], which indicates that blockade of the $\mathrm{A}_{2 \mathrm{~A}}$ receptor-mediated stimulation of cAMP-PKA signaling unlikely contributes to the acute behavioral effects of caffeine, as previously suggested [36]. It is most probable that the coexistence of two apparently incompatible $\mathrm{A}_{2 \mathrm{~A}}-\mathrm{D}_{2}$ receptor interactions in the enkephalinergic MSN depends on the existence of a pool of $\mathrm{A}_{2 \mathrm{~A}}$ and $\mathrm{D}_{2}$ receptors forming heteromers, and a pool of $\mathrm{A}_{2} \mathrm{~A}$ and $\mathrm{D}_{2}$ receptors forming homodimers. When forming homodimers, $D_{2}$ receptor couples preferentially to $G_{i}$, which allows its coupling to adenylyl cyclase. When forming heteromers with the $A_{2 A}$ receptor, the $D_{2}$ receptor cannot activate $\mathrm{G}_{i}$, because a key epitope involved in $\mathrm{Gi}$ activation (an arginine-rich epitope localized in the amino-terminus of the third intracellular loop of the $\mathrm{D}_{2}$ receptor) is also involved in $\mathrm{A}_{2 \mathrm{~A}}-\mathrm{D}_{2}$ receptor heteromerization [37]. In this case, the $\mathrm{D}_{2}$ receptor probably couples to $G_{q / 11}$ with the consequent activation of the PLC pathway [24]. This would be a similar situation to that recently described for the $D_{1}-D_{2}$ receptor heteromer [38].

The allosteric interaction in the $\mathrm{A}_{2 \mathrm{~A}}-\mathrm{D}_{2}$ receptor heteromer seems to play a key role in the motor-activating effects of caffeine. In fact, this $\mathrm{A}_{2 \mathrm{~A}}-\mathrm{D}_{2}$ receptor interaction has been given a lot of attention in the literature, more recently with the application of $\mathrm{A}_{2 \mathrm{~A}}$ receptor antagonists as an adjuvant therapy for L-DOPA in Parkinson's disease (for recent review, see ref. [39]). But, $\mathrm{A}_{1}-\mathrm{D}_{1}$ receptor interactions are also of significant functional and pharmacological importance. Thus, as mentioned before, $\mathrm{A}_{1}$ receptor antagonists potentiate the motor activating effects of $\mathrm{D}_{1}$ receptor stimulation $(40,41)$. Similarly to what happens with $\mathrm{A}_{2 \mathrm{~A}}$ and $\mathrm{D}_{2}$ receptors, antagonistic interactions take place in the $\mathrm{A}_{1}-\mathrm{D}_{1}$ receptor heteromer and at the second messenger level. In this case, the interactions are not reciprocal, and stimulation of $A_{1}$ receptors inhibits both the binding of dopamine to the $\mathrm{D}_{1}$ receptor $[42,43]$ and the $\mathrm{D}_{1}$ receptor-mediated activation of cAMP-PKA signaling pathway and the expression of genes, such as $c$-fos and preprodynorphin in the dynorphinergic MSN $[43,44]$.

\section{Presynaptic mechanisms: Dopamine release}

In addition to the postsynaptic mechanisms related to the $\mathrm{A}_{2 \mathrm{~A}}-\mathrm{D}_{2}$ and $\mathrm{A}_{1}-\mathrm{D}_{1}$ receptor interactions, adenosine also acts presynaptically in the striatal spine module, modulating glutamate and dopamine release. Different studies have repeatedly shown that $\mathrm{A}_{1}$ and $\mathrm{A}_{2 \mathrm{~A}}$ receptors exert opposite modulatory roles on extracellular levels of glutamate and dopamine in the striatum, with activation of $A_{1}$ receptors inhibiting and activation of $A_{2 \mathrm{~A}}$ receptors stimulating glutamate and dopamine release (reviewed in ref. [3]). More recently, we found that systemic or striatal administration of caffeine or an $A_{1}$ but not an $A_{2} \mathrm{~A}$ receptor antagonist produces a significant increase in the extracellular concentrations of glutamate and dopamine in the ventral striatum, particularly in the most medial part, the medial shell of the nucleus accumbens $[45,46]$. It was hypothesized that dopamine release was mostly dependent on glutamate release induced by blockade of $\mathrm{A}_{1}$ receptors localized in glutamatergic terminals and on stimulation of ionotropic glutamate receptors localized in dopaminergic terminals [46]. The ability of caffeine to release dopamine in the nucleus accumbens was questioned by another research group [47], but a recent study demonstrated the existence of subregional differences in the effect of $A_{1}$ receptor blockade in different parts of the nucleus accumbens and other striatal areas, most probably related to subregional differences in the level of tonic activation by endogenous adenosine [31]. Furthermore, glutamate-independent mechanisms were also found to be involved in $\mathrm{A}_{1}$ receptor blockade-mediated striatal dopamine release, which depends on $A_{1}$ receptors localized in dopaminergic nerve terminals [31].

It has been demonstrated with electron-microscopy and immunocytochemical experiments that a high proportion of glutamatergic nerve terminals contain both $\mathrm{A}_{1}$ and $\mathrm{A}_{2 \mathrm{~A}}$ receptors [21]. Recent experiments indicate that $\mathrm{A}_{2 \mathrm{~A}}$ receptors are in fact localized predominantly in glutamatergic terminals that establish contact with dynorphinergic MSNs, which constitute the so-called direct striatal efferent pathway [23]. In functional studies with striatal nerve terminal preparations, stimulation of the $A_{1}$ receptor was found to decrease while stimulation of $\mathrm{A}_{2 \mathrm{~A}}$ receptors potentiated potassium-induced glutamate release [21]. Importantly, when both $\mathrm{A}_{1}$ and $\mathrm{A}_{2 \mathrm{~A}}$ receptors were stimulated, the response was not a counteractive effect, but the same as results from $\mathrm{A}_{2 \mathrm{~A}}$ receptor stimulation, i.e., a potentiation of glutamate release [21]. Furthermore, in the same kind of preparations, low concentrations of 
adenosine inhibited while high concentrations stimulated glutamate release [21]. This would agree with the reported higher affinity for adenosine of the $\mathrm{A}_{1}$ compared to the $A_{2 A}$ receptor [48] and would provide a mechanism for a fine-tuned modulation of glutamate release by adenosine, with low concentrations inhibiting and high concentrations stimulating glutamatergic neurotransmission to the direct striatal efferent pathway. The mechanism by which $\mathrm{A}_{2 \mathrm{~A}}$ receptor stimulation shuts down the effects of $A_{1}$ receptor stimulation seems to be related to an allosteric interaction in $\mathrm{A}_{1}$ $\mathrm{A}_{2 \mathrm{~A}}$ receptor heteromers. Thus, $\mathrm{A}_{1}$ and $\mathrm{A}_{2 \mathrm{~A}}$ receptors have been shown to form heteromers in transfected cells [21]. In membrane preparations from transfected cells and from rat striatum, stimulation of $\mathrm{A}_{2 \mathrm{~A}}$ receptors decreases the affinity of $\mathrm{A}_{1}$ receptor for agonist binding [21].

The question arises as to which is the contribution of $\mathrm{A}_{1}$ and $\mathrm{A}_{2 \mathrm{~A}}$ receptors and the many pre- and postsynaptic mechanisms in the psychostimulant effects of caffeine. There has been a long-running debate about the preferential involvement of $\mathrm{A}_{1}$ and $\mathrm{A}_{2 \mathrm{~A}}$ receptors in the motor-activating effects of caffeine (reviewed in refs. [3,22]) Particularly influential were the experiments with $\mathrm{A}_{2 \mathrm{~A}}$ receptor knockout $\left(\mathrm{A}_{2 \mathrm{~A}} \mathrm{KO}\right)$ mice, which showed a lack of motor-activating effects of caffeine [49]. However, by comparing both quantitative and qualitative aspects of the motor activity induced by caffeine and selective $\mathrm{A}_{1}$ and $\mathrm{A}_{2 \mathrm{~A}}$ receptor antagonists, recent studies have clearly shown that caffeine, when administered acutely, shows a profile of a non-selective adenosine receptor antagonist with even a preferential $\mathrm{A}_{1}$ receptor antagonism [50,51]. Importantly, chronic exposure to caffeine differentially modifies its motor effects dependent on $\mathrm{A}_{1}$ and $\mathrm{A}_{2} \mathrm{~A}$ receptor blockade. Thus, chronic exposure to caffeine in the drinking water of rats results in partial tolerance to the motor effects of an additional acute administration of caffeine, and total cross-tolerance to the motor effects of an $\mathrm{A}_{1}$ but not an $\mathrm{A}_{2 \mathrm{~A}}$ receptor antagonist [50]. This indicates that tolerance to the effects of $A_{1}$ receptor blockade is mostly responsible for the tolerance to the motor-activating effects of caffeine, and that the residual motor-activating effects of caffeine in tolerant individuals might be largely because of $\mathrm{A}_{2 \mathrm{~A}}$ receptor blockade [50]. Numerous experimental findings indicate that dopamine release in the medial striatal compartments is involved in invigoration of approach and in some aspects of incentive learning (for recent review, see ref. [13]). In relation to psychostimulants, dopamine release in the very medial striatal compartments seems to be involved in both their motor-activating and reinforcing effects [13, 52]. Therefore, the pre- and postsynaptic dopaminergic mechanisms mentioned above (striatal dopamine release and adenosine-dopamine receptor-receptor interactions) taking place in the medial striatal compartments are most probably involved in the motor and reinforcing effects of caffeine. Importantly, chronic administration of caffeine in the drinking water completely counteracted the effects of caffeine or an $A_{1}$ receptor antagonist on dopamine and glutamate release, while the effect of an $\mathrm{A}_{2 \mathrm{~A}}$ receptor antagonist was not modified [53]. Thus, these biochemical changes correlate with the studies on motor activity [50], strongly suggesting the involvement of presynaptic mechanisms in the psychostimulant effects of caffeine. In relation to the dopamine-releasing effects, at least two factors could explain the weaker reinforcing properties of caffeine as compared with other psychostimulants: its specific subregional effects [31] and the development of tolerance [50,53].

In summary, caffeine produces its motor and reinforcing effects by releasing the pre- and postsynaptic brakes that adenosine imposes on dopaminergic neurotransmission in the striatal spine module. By targeting $\mathrm{A}_{1}-\mathrm{A}_{2 \mathrm{~A}}$ receptor heteromers in glutamatergic terminals and $A_{1}$ receptors in dopaminergic terminals (presynaptic brake), caffeine induces glutamate-dependent and glutamate-independent release of dopamine. These presynaptic effects of caffeine are potentiated by the release of the postsynaptic brake imposed by antagonistic adenosine-dopamine receptor-receptor interactions in the $\mathrm{A}_{2} \mathrm{~A}-\mathrm{D}_{2}$ and $\mathrm{A}_{1}-\mathrm{D}_{1}$ receptor heteromers. However, it is important to point out the possible additional contribution coming from $\mathrm{A}_{1}$ receptors localized in the nuclei of origin of the ascending dopaminergic systems [54,55].

\section{CAFFEINE AND THE ASCENDING AROUSAL SYSTEMS}

Arousal is a state of behavioral readiness in response to sensory stimulation, which is associated with cortical electroencephalographic (EEG) activation, which depends on the activation of ascending arousal systems localized in the pontomesencephalic tegmentum, basal forebrain and hypothalamus. The arousalenhancing properties of caffeine are mostly dopamineindependent and they are related to its ability to antagonize the sleep-promoting effects of adenosine. To understand the mechanisms involved in caffeine-induced arousal we have to understand how adenosine modulates the function of the ascending arousal systems. 


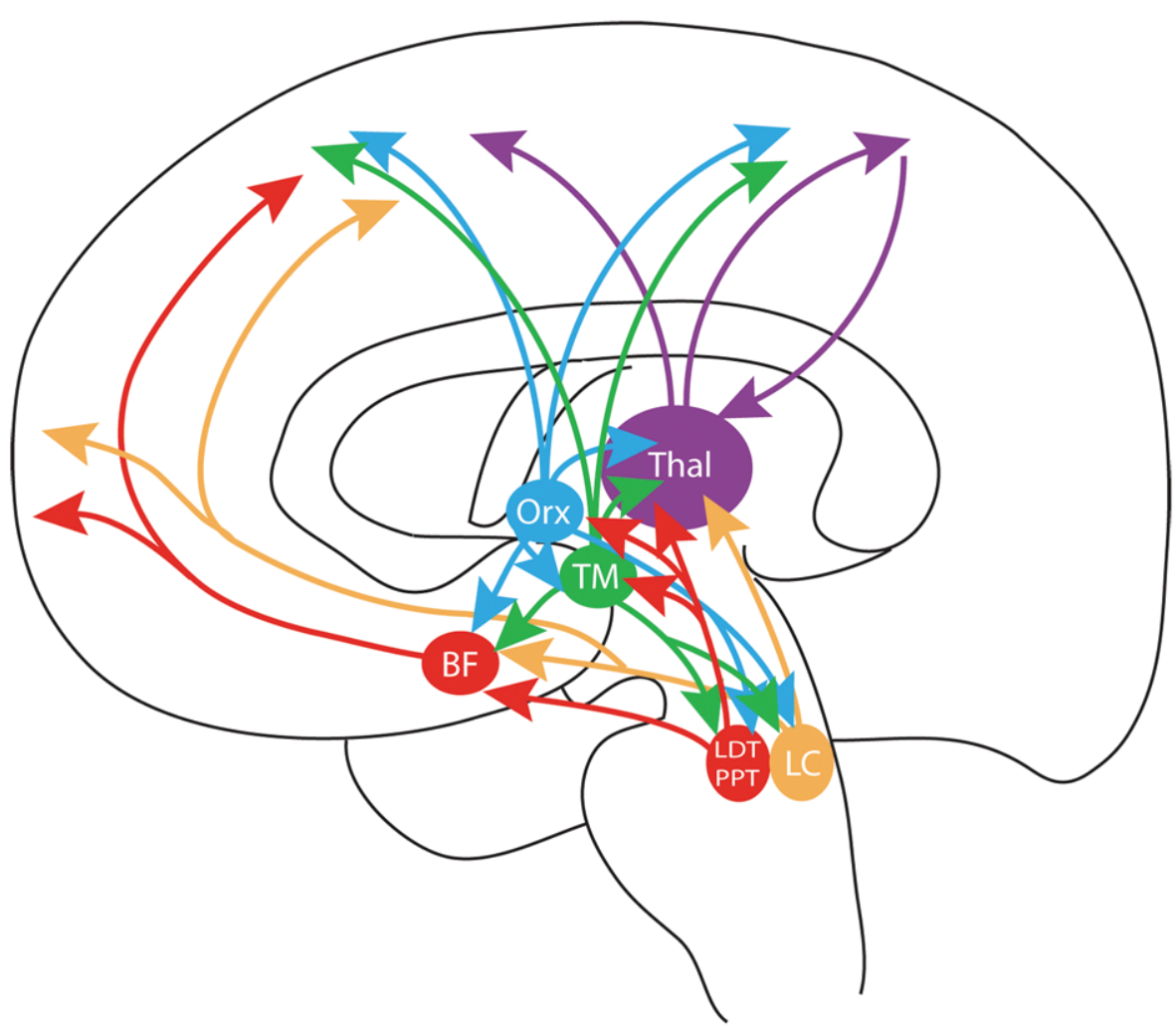

Fig. 2. Scheme of the highly interconnected multiple ascending arousal systems, which are all targets of caffeine (see text). BF: area of origin of the corticopetal basal forebrain system; LC: locus coeruleus; LDT and PPT: laterodorsal and pedunculopontine nuclei; TM: tuberomammilary nucleus; Orx: area of origin of the orexinergic system; Thal: thalamus.

\section{Multiply interconnected ascending arousal systems}

Moruzzi and Magoun, in 1949, were the first to demonstrate that activation of the pontomesencephalic tegmentum, what they called the 'ascending reticular activating system', is associated with arousal [56]. We know now that the ascending reticular activating system is heterogeneous and contains interconnected ascending glutamatergic, cholinergic and noradrenergic pathways [57-59] (Fig. 2). A main characteristic of these chemically defined ascending systems, as well as of the corticopetal basal forebrain system and the hypothalamic ascending systems (see below), is their ability to modulate simultaneously large areas of the brain and synchronize high-frequency cortical activity during the wakefulness period. This characteristic is related to their morphological and functional properties. First, these systems have a relatively low number of cells of origin with widespread branching terminal processes. Second, a synchronization of activity takes place between their cells of origin [60]. Third, their terminals often contain varicosities without synaptic spe- cializations [61] which release neurotransmitters in a "volume transmission" mode [62].

The physiological activation of the ascending reticular system depends on multiple rostral and caudal inputs carrying motor, limbic, visceral and sensorial multimodal information. It even receives an important cortical input from the prefrontal cortex $[63,64]$. The different involvement in cortico-subcortical activation induced by the different ascending glutamatergic, cholinergic and noradrenergic pathways is determined by their preferential target innervation, as well as the different inputs to their pontomesencephalic nuclei of origin [57-59]. Glutamatergic cells of the reticular formation project mostly to the thalamus, to the midlineintralaminar and reticular nuclei, which transmit the activity of the ascending reticular activating system to extensive areas of the cerebral cortex. Most cholinergic cells originate in the laterodorsal and pedunculopontine nuclei (LDT and PPT nuclei), which through a dorsal tegmental pathway also project heavily to the thalamus (Fig. 2). A ventral tegmental pathway forms the extrathalamic cholinergic relay to the cortex and in- 
nervates the cells that are the origin of the corticopetal basal forebrain system (see below) (Fig. 2). It must be pointed out that PPT nucleus is not only cholinergic, but that also contains non-cholinergic cells with extensive projections [65]. In fact, the projection from the PPT nucleus is considered to be largely non-cholinergic and, most probably glutamatergic [66]. Furthermore, some studies indicate that nitric oxide (NO) is an important neuronal messenger of the cholinergic cells of the ascending reticular activating system [67]. Noradrenergic cells originate mostly in the locus coeruleus, just lateral to the LDT nucleus, and project in a diffuse manner to many brain areas, including the thalamus, amygdala, the corticopetal basal forebrain system, and the cerebral cortex [59] (Fig. 2).

The firing of cholinergic neurons of the LDT and PPT nuclei is temporally correlated with cortical activation. The activity of the cholinergic cells decreases during slow-wave sleep and increases again during fast-wave sleep [58]. The activity of brainstem cholinergic neurons during the waking state is not stimulus-specific. This is consistent with their multiple connections with adjacent ascending fiber systems in the reticular formation, as well as with their extensive afferent connections from subcortical limbic (nucleus accumbens) and motor brain areas (substantia nigra pars reticulata, globus pallidus). Animals with PPT nuclei lesions suffer from a global impairment in attention, rather than deficits of specific attention-related tasks [68]. Similarly to the brainstem cholinergic cells, noradrenergic cells of the nucleus coeruleus are also more active during the waking state and less active during slow wavesleep. However, their activity ceases during fast-wave sleep [58]. During the waking state the activity of locus coeruleus cells is decreased when the animal is engaged in automatic, consumatory, non-goal directed motor activity, where it is mostly inattentive to extrapersonal environmental stimuli [69]. Furthermore, different from the brainstem cholinergic cells, the activity of the noradrenergic cells during the waking state is stimulus-specific. Thus, they increase their activity in response to novel or stressful "alerting" stimuli, with the concomitant general increase in cortical activity. This is related to the afferent connections of the nucleus coeruleus from nucleus paragigantocellularis and nucleus prepositus (both located in the rostral medulla) and with the amygdala, brain structures that convey information from emotionally arousing stimuli [70-72]. Animals with lesions of the ascending noradrenergic pathway experience difficulties in some tasks requiring attention, particularly those involving "alerting" stim- uli [59]. Furthermore, there is experimental evidence suggesting that locus coeruleus also plays an important role in attending to non-stressful motivational stimuli [60]. Motivational stimuli most probably influence locus coeruleus by means of its afferent connections with amygdala and prefrontal cortex [71,73].

The corticopetal basal forebrain system is considered as the major extrathalamic relay of the ascending reticular activating system to the cortex $[58,74,75]$. This system represents a continuous stream of cells that extends from the medial septum, through the diagonal band into the substantia innominata, ventral pallidum and nucleus basalis of Meynert [57]. Although it was initially suggested that in both rodents and primates most neurons from the basal forebrain projecting to the cortex were cholinergic, it is now known that in rodents a roughly equal number of basal forebrain GABAergic and cholinergic cells project to cortical areas [76, 77]. Finally, there is also evidence for a glutamatergic component [78]. The corticopetal basal forebrain system innervates the entire telencephalic mantle, including the cerebral cortex, hippocampal formation and amygdala. Main inputs of this system come also from these areas, although the cortical input is restricted to the prefrontal cortex and seems to target preferentially non-cholinergic cells [76,79]. Also, important afferent connections originate in the ventral striatum (motor input), the hypothalamus, the ascending serotoninergic and dopaminergic systems and the different components of the ascending reticular activating system [80], and the ascending hypothalamic arousal systems [81, 82] (Fig. 2). The corticopetal basal forebrain system plays a decisive role in cortical activation. Although the predominantly cortical excitatory role of acethylcholine is well established, GABA is basically an inhibitory neurotransmitter. Nevertheless, GABAergic cells of the corticopetal basal forebrain system induce cortical activation by disinhibition, by targeting the cortical system of GABAergic interneurons [83]. Activity of its cells correlates with cortical activation during waking and fast-wave sleep. During the waking state, the activity of the cells of the corticopetal basal forebrain system is stimulus-specific and specially associated with motivational stimuli [84-86] and motor activity [87]. This is most probably related, first, to the very marked glutamatergic afferent connections from the amygdala and prefrontal cortex, where motivational stimuli are represented [88]. Second, the motor activityrelated changes in cell activity can be mediated by the direct connections from the ventral striatum and the indirect connections from the basal ganglia, through the 
ascending reticular activating system [74,87]. There is an increasing number of experimental data suggesting the existence of anatomical and functional segregated subsystems in the corticopetal basal forebrain, with distinct afferent-efferent connections such as the GABAergic subsystem, that selectively receives input from the prefrontal cortex. These subsystems should afford different roles in different attention processes [76,77].

Two more ascending arousal systems originate in the hypotalamic area: the histaminergic and orexinergic systems, which originate in the caudal and dorsolateral hypothalamus, respectively $[81,82,89-91]$. The same as the noradrenergic (and also the serotoninergic) system, histaminergic and orexinergic cells are active during the waking state, particularly active waking, and virtually inactive during slow and fast-wave sleep [92-94]. Histaminergic cells originate in the tuberomammillary (TM) nuclei of the hypothalamus and innervate diffusely most areas of the brain, including the thalamus and cortex $[81,89]$. TM nuclei receive a main GABAergic-galaninergic inhibitory input from the ventrolateral-preoptic (VLPO) area of the anterior hypothalamus, considered as a main sleep center. Furthermore, TM cells reciprocally connect with LDT and PPT nuclei and project to the origin of the corticopetal basal forebrain system and to the locus coeruleus [81, 92] (Fig. 2).

Orexinergic neurons are localized in the perifornical lateral hypothalamic area, extending medially to the dorsomedial hypothalamic nucleus and sending projections to the midline hypothalamic nuclei, basal forebrain, and cortex, with a very similar distribution to that of the noradrenergic system, with which it is heavily interconnected [82,91]. Their most prominent projections include many hypothalamic areas (including TM nucleus), locus coeruleus (the densest extrahypothalamic projection), basal forebrain, dorsal raphe nucleus, LDT and PPT nuclei, and substantia nigra and ventral tegmental area [82]. The connections with the histaminergic system seem to be particularly relevant and, in fact, several studies strongly suggest that the arousal effects of orexin depend on the activation of the histaminergic system $[95,96]$. Orexin neurons also receive direct projections from the hypothalamus, including TM nucleus, VLPO area and the suprachiasmatic nucleus, which is critically involved in the generation of circadian rhythm [97] (Fig. 2).

The ascending dopaminergic and serotoninergic pathways, which also originate in the brainstem and innervate diffusely many brain areas including the cerebral cortex, are often included as part of the ascending reticular activating system (see, for instance, ref. [59]). However, these systems are not 'directly' involved in arousal or attention. Nevertheless, the activity of serotoninergic cells (but not dopaminergic cells) is statedependent, and their firing is maximal during the waking state, decreases during slow-wave sleep and stops during fast-wave sleep. During the wakefulness period, the activity of the ascending serotoninergic cells, which originate in the dorsal and median raphe nuclei, does not vary with any kind of sensorial stressful or non-stressful stimulation. On the other hand, just opposite to what happens with locus coeruleus cells, they increase their activity during automatic, consumatory, non-goal directed motor activity [98].

\section{Adenosinergic modulation of the ascending arousal systems}

An important amount of evidence indicates that adenosine is a mediator of sleepiness following prolonged wakefulness. Initial evidence came from pharmacological studies showing the sleep-inducing effects of systemic or intracerebral administration of adenosine and adenosine receptor agonists (reviewed in ref. [99]). These results, together with the fact that adenosine is a byproduct of energy metabolism and that energy restoration seems to be one of the main functions of sleep, led to the hypothesis that adenosine may serve as a homeostatic regulator of energy. Although it was initially thought that adenosine would accumulate in the extracellular space as a function of neuronal activity, either following its equilibrative transport or after metabolization from released ATP, recent studies indicate that sleep homeostasis depends largely upon gliotransmission. Thus, inhibiting gliotransmission, and therefore glial ATP release (ATP and glutamate are the main glial neurotransmitters), attenuated the sleep pressure following sleep deprivation and prevented the arousing effects of $A_{1}$ receptor antagonists [100].

After prolonged wakefulness in the cat, adenosine was found to accumulate in the basal forebrain and to a lesser extent in the cerebral cortex [101]. This accumulation was brain region-specific and adenosine was not found to increase in thalamus, preoptic hypothalamic area, PPT, or dorsal raphe [101]. The rise of adenosine levels inhibits the firing of the cells of origin of the corticopetal basal forebrain system, and experiments with selective ligands indicate that $\mathrm{A}_{1}$ receptors are preferentially involved $[99,102]$. Nevertheless the activity of LDT/PPT cells is also under an inhibitory local tone by endogenous adenosine through the acti- 
vation of $A_{1}$ receptors, probably localized both postsynaptically and presynaptically in glutamatergic terminals $[103,104]$. Furthermore, recent experiments indicate that stimulation and blockade of $\mathrm{A}_{1}$ receptors in the prefrontal cortex decreases and increases arousal, respectively, and that this modulation is mediated by the descending connection from the prefrontal cortex to the PPT/LTD [105].

However, the sleep-generating effects of adenosine entail additional and not less important modulations of the other ascending arousal systems. As mentioned before, the hypothalamic VLPO area (and the adjacent median preoptic nucleus) is an important sleep center, and anatomical and physiological evidences suggest that the preoptic area neurons promote sleep via descending inhibitory modulation of the arousal system. The GABAergic-galaninergic cells of the VLPO project heavily to the histaminergic TM nuclei, and electrical stimulation of the VLPO area inhibits neuronal excitability of the histaminergic cells [106]. Physiologically, VLPO area is activated by endogenous sleep promoting substances that accumulate during the waking state, including adenosine and prostaglandin $\mathrm{D}_{2}$ $\left(\mathrm{PGD}_{2}\right)[107,108]$. Activation by adenosine is mediated by $\mathrm{A}_{2 \mathrm{~A}}$ receptors localized in a subset of VLPO neurons [109], and the sleep-enhancing effects of $\mathrm{PGD}_{2}$ also seem to require activation of VLPO sleep regulatory neurons by adenosine acting at $\mathrm{A}_{2 \mathrm{~A}}$ receptors [109]. Apart from the connection to the TM nuclei, GABAergic cells from the VLPO also project to the locus ceruleus and the perifornical lateral hypothalamic area and several experimental findings suggest that deactivation of the histaminergic, noradrenergic and orexinergic arousal systems occurring at sleep onset and during the fast- and slow-wave sleep results from GABA-mediated inhibition originating in the preoptic hypothalamus [108].

In summary, it is now generally believed that the direct $\mathrm{A}_{1}$-receptor mediated modulation of the corticopetal basal forebrain system and the indirect $\mathrm{A}_{2 \mathrm{~A}^{-}}$ receptor mediated modulation of the hypothalamic histaminergic and orexinergic systems are the main mechanisms by which adenosine exerts its sleep-promoting effects [102,108]. However, it is important to point out the possible additional contribution coming from $\mathrm{A}_{1}$ receptors localized in the nuclei of origin of the histaminergic, orexinergic and noradrenergic arousal systems [110-112].

The same as for the motor-activating effects of caffeine, there has been a strong debate about the role of $A_{1}$ and $A_{2 A}$ receptors in its arousing effects. Sim- ilarly to the studies on motor activation, $\mathrm{A}_{1}$ receptors (in the basal forebrain) were initially the main candidates (reviewed in ref. [102]), but again experiments performed in $\mathrm{A}_{2 \mathrm{~A}} \mathrm{KO}$ mice strongly suggested a predominant role of $\mathrm{A}_{2 \mathrm{~A}}$ receptors [113]. $\mathrm{A}_{2 \mathrm{~A}} \mathrm{KO}$ did not show slow-wave sleep rebound after sleep deprivation while $\mathrm{A}_{1} \mathrm{KO}$ did. Furthermore, caffeine induced wakefulness in wild-type and $\mathrm{A}_{1} \mathrm{KO}$, but not in $\mathrm{A}_{2 \mathrm{~A}} \mathrm{KO}$ mice (reviewed in ref. [114]). However, recent studies using conditional CNS $\mathrm{A}_{1} \mathrm{KO}$ mice question the validity of the apparently obvious interpretations of experiments with adenosine receptor KO mice [114], underscoring the limitations of the global absence of a gene during development. Thus, conditional $\mathrm{CNS}_{1} \mathrm{KO}$ mice showed a significant attenuation of the slow-wave EEG activity rebound response to restricted sleep and they also fail to maintain cognitive performance in a working memory task [114]. Nevertheless, recent experiments that measure c-Fos immunoreactivity to measure neuronal activation showed that behaviorally relevant doses of caffeine induce a remarkably restricted pattern of c-Fos expression in the ascending arousal systems. Those studies support a predominant activating effect of caffeine of the orexinergic, histaminergic and noradrenergic systems [115]. Surprisingly, caffeine induced very little or no effect on the cholinergic neurons of the basal forebrain or mesopontine tegmentum [115], which might call into question the generally accepted validity of c-Fos as a universal marker of neuronal activation. In summary, when considering all the results obtained from different studies, there seems to be evidence for a role of an $\mathrm{A}_{1}$-receptor mediated modulation of the corticopetal basal forebrain system and a complex $\mathrm{A}_{1}$ and $\mathrm{A}_{2 \mathrm{~A}}$ receptor mediated modulation (direct and indirect, respectively) of the noradrenergic system and the hypothalamic histaminergic and orexinergic systems in the arousing effects of caffeine.

\section{CONCLUSION}

The study of the psychostimulant effects of caffeine implies the analysis of the multiple effects of endogenous adenosine on multiple ascending neurotransmitter systems. It is obvious that only an integrative view of those effects can allow us to understand the mechanisms of action of the most consumed psychoactive drug in the world. We have explicitly separated motoractivating (and reinforcing) and arousing properties by separating the dopaminergic systems from the ascending arousal systems. But even this separation can be 
artifactual. One of the purposes of this review is to show the tight interconnectivity between all the central ascending neurotransmitter systems. As described above, some of the most important inputs to the areas of origin of the ascending arousal systems come from motor brain areas, from the basal ganglia, including the substantia nigra and ventral tegmental area. It was also mentioned that, in fact, the activity of the cells of the corticopetal basal forebrain system is not only associated with motivational stimuli but also with motor activity [87]. That means that some of the arousing effects of caffeine may be secondary to an increased motor activation. In this respect, a recent study in mice with a selective inactivation of striatal $\mathrm{A}_{2 \mathrm{~A}}$ receptors showed that in these animals both motor-activating and arousing properties of caffeine were compromised [116]. An additional level of complexity arises when looking at a more molecular level, at the level of local modules, where we discover that the main targets of caffeine $\left(\mathrm{A}_{1}\right.$ and $\mathrm{A}_{2 \mathrm{~A}}$ receptors) are localized in different parts of different neuronal and glial elements where they form different receptor heteromers. We seem to be quite advanced in our understanding of the modulatory role of adenosine in the striatal local modules (striatal spine module), but this is just one of the terminal fields of the ascending dopaminergic systems. To reach a complete understanding of the mechanisms behind the psychostimulant effects of caffeine we still need to find out about the role of adenosine, adenosine receptors, and adenosine receptor heteromers in local modules from all the other areas of origin and projection of the ascending dopaminergic and arousal systems. Furthermore, we are only starting to understand the mechanisms underlying some temporal properties of the psycostimulant effects of caffeine, such as sensitization and tolerance [22,50,117-119]. In addition to pharmacokinetic mechanisms [117], we need to establish which pharmacodynamic changes, such as modifications in the expression and function of adenosine and dopamine receptors and receptor heteromers [22,50,119], are involved. Some of these temporal effects, particularly sensitization, which is known to be a context-dependent process for classical psychostimulant [120], might be related to the ability of adenosine to modulate longlasting, activity-dependent changes in synaptic efficacy at excitatory synapses, particularly in the striatum [20]. Nevertheless, in the meantime, caffeine shows to be a very good pharmacological tool to investigate the functions of the central ascending neurotransmitter systems.

\section{ACKNOWLEDGMENTS}

Work supported with the intramural funds of the National Institute on Drug Abuse.

Authors' disclosures available online (http://www.jalz.com/disclosures/view.php?id=243).

\section{REFERENCES}

[1] Fredholm BB, Battig K, Holmen J, Nehlig A, Zvartau EE (1999) Actions of caffeine in the brain with special reference to factors that contribute to its widespread use. Pharmacol Rev 51, 83-133.

[2] Griffiths RR, Juliano LM, Chausmer A (2003) Caffeine: Pharmacology and Clinical Effects. In Principles of Addiction Medicine, Graham AW, Schultz TK, Mayo-Smth MF, Ries RK, Wilford BB, eds, Third Edition, American Society of Addiction Medicine, Chevy Chase, pp. 193-224.

[3] Ferré S (2008) An update on the mechanisms of the psychostimulant effects of caffeine. J Neurochem 105, 1067-1079.

[4] Griffiths RR, Woodson PP (1988) Reinforcing effects of caffeine in humans. J Pharmacol Exp Ther 246, 21-29.

[5] Mumford GK, Holtzman SG (1991) Qualitative differences in the discriminative stimulus effects of low and high doses of caffeine in the rat. J Pharmacol Exp Ther 258, 857-865.

[6] Munzar P, Justinova Z, Kutkat SW, Ferré S, Goldberg SR (2002) Adenosinergic modulation of the discriminativestimulus effects of methamphetamine in rats. Psychopharmacology 161, 348-355.

[7] Solinas M, Ferré S, Antoniou K, Quarta D, Justinova Z, Hockemeyer J, Pappas LA, Segal PN, Wertheim C, Muller CE, Goldberg SR (2005) Involvement of adenosine A1 receptors in the discriminative-stimulus effects of caffeine in rats. Psychopharmacology 179, 576-586.

[8] Fredholm BB, Ijzerman A P, Jacobson KA, Klotz KN, Linden J (2001) International Union of Pharmacology. XXV. Nomenclature and classification of adenosine receptors. Pharmacol Rev 53, 527-552.

[9] Schiffmann SN, Fisone G, Moresco R, Cunha R, Ferré S (2007) Adenosine A2A receptors and basal ganglia physiology. Prog Neurobiol 83, 277-292.

[10] Ferré S, Fuxe K, von Euler G, Johansson B, Fredholm BB (1992) Adenosine-dopamine interactions in the brain. $\mathrm{Neu}$ roscience 51, 501-512.

[11] Garrett BE, Griffiths RR (1997) The role of dopamine in the behavioral effects of caffeine in animals and humans. Pharmacol Biochem Behav 57, 533-541.

[12] Wise RA (2004) Dopamine, learning and motivation. Nat Neurosci Rev 5, 483-494.

[13] Ikemoto S (2007) Dopamine reward circuitry: Two projection systems from the ventral midbrain to the nucleus accumbens-olfactory tubercle complex. Brain Res Rev 56, 27-78.

[14] Gerfen CR (2004) Basal Ganglia. In The Rat Nervous System, Paxinos G., ed., Elsevier Academic Press, Amsterdam, pp. 445-508.

[15] Ferré S, Fredholm BB, Morelli M, Popoli P, Fuxe K (1997) Adenosine-dopamine receptor-receptor interactions as an integrative mechanism in the basal ganglia. Trends Neurosci 20, $482-487$. 
[16] Ferré S, Agnati LF, Ciruela F, Lluis C, Woods AS, Fuxe K, Franco R (2007) Neurotransmitter receptor heteromers and their integrative role in 'local modules': The striatal spine module. Brain Res Rev 55, 55-67.

[17] Newman EA (2003) New roles for astrocytes: Regulation of synaptic transmission. Trends Neurosci 26, 536-542.

[18] Hertz L, Zielke R (2004) Astrocytic control of glutamatergic activity: astrocytes as stars of the show. Trends Neurosci 27, 735-743.

[19] Pascual O, Casper KB, Kubera C, Zhang J, Revilla-Sanchez R, Sul JY, Takano H, Moss SJ, McCarthy K, Haydon PG (2005) Astrocytic purinergic signaling coordinates synaptic networks. Science 310, 113-116.

[20] Ferré S, Borycz J, Goldberg SR, Hope BT, Morales M, Lluis C, Franco R, Ciruela F, Cunha R (2005) Role of adenosine in the control of homosynaptic plasticity in striatal excitatory synapses. J Integr Neurosci 4, 445-464.

[21] Ciruela F, Casado V, Rodrigues RJ, Lujan R, Burgueno J, Canals M, Borycz J, Rebola N, Goldberg SR, Mallol J, Cortes A, Canela EI, Lopez-Gimenez JF, Milligan G, Lluis C, Cunha RA, Ferré S, Franco R (2006) Presynaptic control of striatal glutamatergic neurotransmission by adenosine A1-A2A receptor heteromers. J Neurosci 26, 2080-2087.

[22] Ferré S, Ciruela F, Borycz J, Solinas M, Quarta D, Antoniou K, Quiroz C, Justinova Z, Lluis C, Franco R, Goldberg SR (2008) Adenosine A1-A2A receptor heteromers: new targets for caffeine in the brain. Front Biosci 13, 2391-2399.

[23] Quiroz C, Lujan R, Uchigashima M, Simoes A, Lerner TN, Borycz J, Kachroo A, Canas PM, Orru M, Schwarzchild M, Rosin DL, Kreitzer AC, Cunha RA, Watanabe M, Ferré S (2009) Key modulatory role of presynaptic adenosine A2A receptors in cortical neurotransmission to the striatal direct pathway. ScientificWorldJournal 9, 1321-1344.

[24] Ferré S, Quiroz C, Woods AS, Cunha R, Popoli P, Ciruela F, Lluis C, Franco R, Azdad K, Schiffmann SN. An update on adenosine A2A-dopamine D2 receptor interactions: implications for the function of $\mathrm{G}$ protein-coupled receptors. Curr Pharm Des 14, 1468-1474.

[25] Rosin DL, Hettinger BD, Lee A, Linden J (2003) Anatomy of adenosine A2A receptors in brain: morphological substrates for integration of striatal function. Neurology 61, S12-S18.

[26] Gomes CA, Vaz SH, Ribeiro JA, Sebastiao AM (2006) Glial cell line-derived neurotrophic factor (GDNF) enhances dopaminerelease from striatal nerve endings in an adenosine A2A receptor-dependent manner. Brain Res 1113, 129-136.

[27] Gomes CA, Simões PF, Canas PM, Quiroz C, Sebastião AM, Ferré S, Cunha RA, Ribeiro JA (2009) GDNF control of the glutamatergic cortico-striatal pathway requires tonic activation of adenosine A2A receptors. J Neurochem 108, 12081219.

[28] Shindou T, Arbuthnott GW, Wickens JR (2008) Actions of adenosine A2A receptors on synaptic connections of spiny projection neurons in the neostriatal inhibitory network. $J$ Neurophysiol 99, 1884-1889.

[29] Mori A, Shindou T (2003) Modulation of GABAergic transmission in the striatopallidal system by adenosine A2A receptors: a potential mechanism for the antiparkinsonian effects of A2A antagonists. Neurology 61, S44-S48.

[30] Preston Z, Lee K, Widdowson L, Freeman TC, Dixon AK, Richardson PJ (2000) Adenosine receptor expression and function in rat striatal cholinergic interneurons. $\mathrm{Br} J$ Pharmacol 130, 886-890.

[31] Borycz J, Pereira MF, Melani A, Rodrigues RJ, Kofalvi A, Panlilio L, Pedata F, Goldberg SR, Cunha RA, Ferré
S (2007) Differential glutamate-dependent and glutamateindependent adenosine A1 receptor-mediated modulation of dopamine release in different striatal compartments. $\mathrm{J} \mathrm{Neu}$ rochem 101, 355-363.

[32] Ferré S, Ciruela F, Quiroz C, Luján R, Popoli P, Cunha RA, Agnati LF, Fuxe K, Woods AS, Lluis C, Franco R (2007) Adenosine receptor heteromers and their integrative role in striatal function. ScientificWorldJournal 7, 74-85.

[33] Ferré S, von Euler G, Johansson B, Fredholm BB, Fuxe K (1991) Stimulation of high-affinity adenosine A2 receptors decreases the affinity of dopamine D2 receptors in rat striatal membranes. Proc Natl Acad Sci U S A 88, 7238-7241.

[34] Ferré S, O'Connor WT, Fuxe K, Ungerstedt U (1993) The striopallidal neuron: a main locus for adenosine-dopamine interactions in the brain. J Neurosci 13, 5402-5406.

[35] Azdad K, Gall D, Woods AS, Ledent C, Ferré S, Schiffmann SN (2009) Dopamine D2 and adenosine A2A receptors regulate NMDA-mediated excitation in accumbens neurons through A2A-D2 receptor heteromerization. Neuropsychopharmacology 34, 972-986.

[36] Lindskog M, Svenningsson P, Pozzi L, Kim Y, Fienberg AA, Bibb JA, Fredholm BB, Nairn AC, Greengard P, Fisone G (2002) Involvement of DARPP-32 phosphorylation in the stimulant action of caffeine. Nature 418, 774-778.

[37] Woods AS, Ferré S (2005) Amazing stability of the argininephosphate electrostatic interaction. J Proteome Res 4 , 13971402

[38] Rashid AJ, So CH, Kong MM, Furtak T, El-Ghundi M, Cheng R, O'Dowd BF, George SR (2007) D1-D2 dopamine receptor heterooligomers with unique pharmacology are coupled to rapid activation of Gq/11 in the striatum. Proc Natl Acad Sci U S A 104, 654-659.

[39] Muller CE, Ferré S (2007) Blocking striatal adenosine A2A receptors: A new strategy for basal ganglia disorders. Recent Pat CNS Drug Disc 2, 1-21.

[40] Popoli P, Gimenez-Llort L, Pezzola A, Reggio R, Mart́nez E, Fuxe K, Ferré S (1996) Adenosine A1 receptor blockade selectively potentiates the motor effects induced by dopamine D1 receptor stimulation in rodents. Neurosci Lett 218, 209213.

[41] Ferré S, Popoli P, Giménez-Llort L, Rimondini R, Müller CE, Strömberg I, Ögren SO, Fuxe K (2001) Adenosine/dopamine interaction: implications for the treatment of Parkinson's disease. Parkinsonism Relat Disord 7, 235-241.

[42] Ferré S, Popoli P, Giménez-Llort L, Finnman UB, Martínez E, Scotti de Carolis A, Fuxe K (1994) Postsynaptic antagonistic interaction between adenosine A1 and dopamine D1 receptors. Neuroreport 6, 73-76.

[43] Ferré S, Torvinen M, Antoniou K, Irenius E, Civelli O, Arenas E, Fredholm BB, Fuxe K (1998) Adenosine A1 receptormediated modulation of dopamine D1 receptors in stably cotransfected fibroblast cells. J Biol Chem 273, 4718-4724.

[44] Ferré S, Rimondini R, Popoli P, Reggio R, Pezzola A, Hansson AC, Andersson A, Fuxe K (1999) Stimulation of adenosine $\mathrm{A} 1$ receptors attenuates dopamine $\mathrm{D} 1$ receptor-mediated increase of NGFI-A, c-fos and jun-B mRNA levels in the dopamine-denervated striatum and dopamine D1 receptormediated turning behaviour. Eur J Neurosci 11, 3884-3892.

[45] Solinas M, Ferré S, You ZB, Karcz-Kubicha M, Popoli P, Goldberg SR (2002) Caffeine induces dopamine and glutamate release in the shell of the nucleus accumbens. JNeurosci 22, 6321-6324.

[46] Quarta D, Borycz J, Solinas M, Patkar K, Hockemeyer J, Ciruela F, Lluis C, Franco R, Woods AS, Goldberg SR, 
Ferré S (2004) Adenosine receptor-mediated modulation of dopamine release in the nucleus accumbens depends on glutamate neurotransmission and N-methyl-D-aspartate receptor stimulation. J Neurochem 91, 873-880.

[47] De Luca MA, Bassareo V, Bauer A, Di Chiara G (2007) Caffeine and accumbens shell dopamine. J Neurochem 103, 157-63.

[48] Fredholm BB, Irenius E, Kull B, Schulte G (2001) Comparison of the potency of adenosine as an agonist at human adenosine receptors expressed in Chinese hamster ovary cells. Biochem Pharmacol 61, 443-448.

[49] Ledent C, Vaugeois JM, Schiffmann SN, Pedrazzini T, El Yacoubi M, Vanderhaeghen JJ, Costentin J, Heath JK, Vassart G, Parmentier M (1997) Aggressiveness, hypoalgesia and high blood pressure in mice lacking the adenosine A2a receptor. Nature 388, 674-678.

[50] Karcz-Kubicha M, Antoniou K, Terasmaa A, Quarta D, Solinas M, Justinova Z, Pezzola A, Reggio R, Muller CE, Fuxe K, Goldberg SR, Popoli P, Ferré S (2003) Involvement of adenosine $\mathrm{A} 1$ and $\mathrm{A} 2 \mathrm{~A}$ receptors in the motor effects of caffeine after its acute and chronic administration. Neuropsychopharmacology 28, 1281-1291.

[51] Antoniou K, Papadopoulou-Daifoti Z, Hyphantis T, Papathanasiou G, Bekris E, Marselos M, Panlilio L, Muller CE, Goldberg SR, Ferré S (2005) A detailed behavioral analysis of the acute motor effects of caffeine in the rat: involvement of adenosine A1 and A2A receptors. Psychopharmacology 183, 154-162.

[52] Di Chiara G (2002) Nucleus accumbens shell and core dopamine: differential role in behavior and addiction. Behav Brain Res 137, 75-114.

[53] Quarta D, Ferré S, Solinas M, You ZB, Hockmeyer J, Popoli P, Goldberg SR (2004) Opposite modulatory roles for adenosine $A_{1}$ and $A_{2} A$ receptors on glutamate and dopamine release in the shell of the nucleus accumbens. Effects of chronic caffeine exposure. J Neurochem $\mathbf{8 8}, 1151-1158$.

[54] Fiorillo CD, Williams JT (2000) Selective inhibition by adenosine of mGluR IPSPs in dopamine neurons after cocaine treatment. J Neurophysiol 83, 1307-1314.

[55] Kaplan GB, Leite-Morris KA, Klufas MA, Fan W (2009) Intra-VTA adenosine A1 receptor activation blocks morphine stimulation of motor behavior and cortical and limbic Fos immunoreactivity. Eur J Pharmacol 602, 268-276.

[56] Moruzzi G, Magoun HW (1949) Brain stem reticular formation and activation of the EEG. Electroencephalogr Clin Neurophysiol 1, 455-473.

[57] Jones BE (1993) The organization of central cholinergic systems and their functional importance in sleep-waking states. Prog Brain Res 98, 61-71.

[58] Jones BE (1998) The neural basis of consciousness across the sleep-waking cycle. Adv Neurol 77, 75-94.

[59] Robbins TW (1997) Arousal systems and attentional processes. Biol Psychol 45, 57-71.

[60] Usher M, Cohen JD, Servan-Schreiber D, Rajkowski J, Aston-Jones G (1999) The role of locus coeruleus in the regulation of cognitive performance. Science 283, 549-554.

[61] Descarries L, Mechawar N (2000) Ultrastructural evidence for diffuse transmission by monoamine and acetylcholine neurons of the central nervous system. Prog Brain Res 125, 27-47.

[62] Zoli M, Jansson A, Sykova E, Agnati LF, Fuxe K (1999) Volume transmission in the CNS and its relevance for neuropsychopharmacology. Trends Pharmacol Sci 20, 142-150.
[63] Arnsten AF, Goldman-Rakic PS (1984) Selective prefrontal cortical projections to the region of the locus coeruleus and raphe nuclei in the rhesus monkey. Brain Res 306, 9-18.

[64] Semba K, Fibiger HC (1992) Afferent connections of the laterodorsal and the pedunculopontine tegmental nuclei in the rat: a retro- and antero-grade transport and immunohistochemical study. J Comp Neurol 323, 387-410.

[65] Inglis WL, Winn P (1995) The pedunculopontine tegmental nucleus: where the striatum meets the reticular formation. Prog Neurobiol 47, 1-29.

[66] Rasmusson DD, Clow K, Szerb JC (1994) Modification of neocortical acetylcholine release and electroencephalogram desynchronization due to brainstem stimulation by drugs applied to the basal forebrain. Neuroscience 60, 665-677.

[67] Vincent SR (2000) The ascending reticular activating system - from aminergic neurons to nitric oxide. J Chem Neuroanat 18, 23-30.

[68] Inglis WL, Olmstead MC, Robbins TW (2001) Selective deficits in attentional performance on the 5-choice serial reaction time task following pedunculopontine tegmental nucleus lesions. Behav Brain Res 123, 117-131.

[69] Aston-Jones G, Rajkowski J, Cohen J (1999) Role of locus coeruleus in attention and behavioral flexibility. Biol Psychiatry 46, 1309-1320.

[70] Aston-Jones G, Rajkowski J, Kubiak P, Valentino RJ, Shipley MT (1996) Role of the locus coeruleus in emotional activation. Prog Brain Res 107, 379-402.

[71] Van Bockstaele EJ, Peoples J, Valentino RJ (1999) A.E. Bennett Research Award. Anatomic basis for differential regulation of the rostrolateral peri-locus coeruleus region by limbic afferents. Biol Psychiatry 46, 1352-1363.

[72] Clayton EC, Williams CL (2000) Glutamatergic influences on the nucleus paragigantocellularis: contribution to performance in avoidance and spatial memory tasks. Behav Neurosci 114, 707-712.

[73] Sara SJ, Herve-Minvielle A (1995) Inhibitory influence of frontal cortex on locus coeruleus neurons. Proc Natl Acad Sci U S A 92, 6032-6036.

[74] Perry E, Walker M, Grace J, Perry R (1999) Acetylcholine in mind: a neurotransmitter correlate of consciousness? Trends Neurosci 22, 273-280.

[75] Sarter M, Bruno JP (2000) Cortical cholinergic inputs mediating arousal, attentional processing and dreaming: differential afferent regulation of the basal forebrain by telencephalic and brainstem afferents. Neuroscience 95, 933-952.

[76] Zaborszky L, Pang K, Somogyi J, Nadasdy Z, Kallo I (1999) The basal forebrain corticopetal system revisited. Ann NY Acad Sci 877, 339-367.

[77] Sarter M, Bruno JP (2002) The neglected constituent of the basal forebrain corticopetal projection system: GABAergic projections. Eur J Neurosci 15, 1867-1873.

[78] Manns ID, Alonso A, Jones B (2003) Rhythmically discharging Basal forebrain units comprise cholinergic, GABAergic, and putative glutamatergic cells. J Neurophysiol 89, 10571066.

[79] Gyengési E, Zaborszky L, Détári L (2008) The effect of prefrontal stimulation on the firing of basal forebrain neurons in urethane anesthetized rat. Brain Res Bull 75, 570-580.

[80] Zaborszky L, Gaykema RP, Swanson DJ, Cullinan WE (1997) Cortical input to the basal forebrain. Neuroscience 79, 1051-78.

[81] Brown RE, Stevens DR, Haas HL (2001) The physiology of brain histamine. Prog Neurobiol 63, 637-672. 
[82] Peyron C, Tighe DK, van den Pol AN, de Lecea L, Heller HC, Sutcliffe JG, Kilduff TS (1998) Neurons containing hypocretin (orexin) project to multiple neuronal systems. J Neurosci 18, 9996-10015.

[83] Freund TF, Meskenaite V (1992) gamma-Aminobutyric acidcontaining basal forebrain neurons innervate inhibitory interneurons in the neocortex. Proc Natl Acad Sci U S A 89, 738-742.

[84] Richardson RT, DeLong MR (1990) Context-dependent responses of primate nucleus basalis neurons in a go/no-go task. J Neurosci 10, 2528-2540.

[85] Wilson FA, Rolls ET (1990) Learning and memory is reflected in the responses of reinforcement-related neurons in the primate basal forebrain. J Neurosci 10, 1254-1267.

[86] Pirch JH (1993) Basal forebrain and frontal cortex neuron responses during visual discrimination in the rat. Brain Res Bull 31, 73-83.

[87] Szymusiak R, Alam N, McGinty D (2000) Discharge patterns of neurons in cholinergic regions of the basal forebrain during waking and sleep. Behav Brain Res 115, 171-182.

[88] Rolls ET (2000) The orbitofrontal cortex and reward. Cereb Cortex 10, 284-294.

[89] Wada H, Inagaki N, Yamatodani A, Watanabe T (1991) Is the histaminergic neuron system a regulatory center for wholebrain activity? Trends Neurosci 14, 415-418.

[90] Mignot E, Taheri S, Nishino S (2002) Sleeping with the hypothalamus: emerging therapeutic targets for sleep disorders. Nat Neurosci 5(Suppl), 1071-1075.

[91] Baldo BA, Daniel RA, Berridge CW, Kelley AE (2003) Overlapping distributions of orexin/hypocretin- and dopaminebeta-hydroxylase immunoreactive fibers in rat brain regions mediating arousal, motivation, and stress. J Comp Neurol 464, 220-237.

[92] Lee MG, Hassani OK, Jones BE (2005) Discharge of identified orexin/hypocretin neurons across the sleep-waking cycle. J Neurosci 25, 6716-6720.

[93] Mileykovskiy BY, Kiyashchenko LI, Siegel JM (2005) Behavioral correlates of activity in identified hypocretin/orexin neurons. Neuron 46, 787-798.

[94] Takahashi K, Lin JS, Sakai K (2006) Neuronal activity of histaminergic tuberomammillary neurons during wake-sleep states in the mouse. J Neurosci 26, 10292-10298.

[95] Eriksson KS, Sergeeva O, Brown RE, Haas HL (2001) Orexin/hypocretin excites the histaminergic neurons of the tuberomammillary nucleus. J Neurosci 21, 9273-9279.

[96] Huang ZL, Qu WM, Li WD, Mochizuki T, Eguchi N, Watanabe T, Urade Y, Hayaishi O (2001) Arousal effect of orexin A depends on activation of the histaminergic system. Proc Natl Acad Sci U S A 98, 9965-9970.

[97] Yoshida K, McCormack S, España RA, Crocker A, Scammell TE (2006) Afferents to the orexin neurons of the rat brain. $J$ Comp Neurol 494, 845-861.

[98] Jacobs BL, Fornal CA (1999) Activity of serotonergic neurons in behaving animals. Neuropsychopharmacology 21(Suppl 2), 9S-15S.

[99] Basheer R, Strecker RE, Thakkar MM, McCarley RW (2004) Adenosine and sleep-wake regulation. Prog Neurobiol 73, 379-396.

[100] Halassa MM, Florian C, Fellin T, Munoz JR, Lee SY, Abel T, Haydon PG, Frank MG (2009) Astrocytic modulation of sleep homeostasis and cognitive consequences of sleep loss. Neuron 61, 213-219.

[101] Porkka-Heiskanen T, Strecker RE, McCarley RW (2000) Brain site-specificity of extracellular adenosine concentra- tion changes during sleep deprivation and spontaneous sleep: an in vivo microdialysis study. Neuroscience 99, 507-517.

[102] McCarley RW (2007) Neurobiology of REM and NREM sleep. Sleep Med 8, 302-330.

[103] Rainnie DG, Grunze HC, McCarley RW, Greene RW (1994) Adenosine inhibition of mesopontine cholinergic neurons: implications for EEG arousal. Science 263, 689-692.

[104] Arrigoni E, Rainnie DG, McCarley RW, Greene RW (2001) Adenosine-mediated presynaptic modulation of glutamatergic transmission in the laterodorsal tegmentum. J Neurosci 21, 1076-1085.

[105] Van Dort CJ, Baghdoyan HA, Lydic R (2009) Adenosine $\mathrm{A}(1)$ and $\mathrm{A}(2 \mathrm{~A})$ receptors in mouse prefrontal cortex modulate acetylcholine release and behavioral arousal. J Neurosci 29, 871-881.

[106] Yang QZ, Hatton GI (1997) Electrophysiology of excitatory and inhibitory afferents to rat histaminergic tuberomammillary nucleus neurons from hypothalamic and forebrain sites. Brain Res 773, 162-172.

[107] Strecker RE, Morairty S, Thakkar MM, Porkka-Heiskanen T, Basheer R, Dauphin LJ, Rainnie DG, Portas CM, Greene RW, McCarley RW (2000) Adenosinergic modulation of basal forebrain and preoptic/anterior hypothalamic neuronal activity in the control of behavioral state. Behav Brain Res 115, 183-204.

[108] Szymusiak R, McGinty D (2008) Hypothalamic regulation of sleep and arousal. Ann N Y Acad Sci 1129, 275-286.

[109] Huang ZL, Urade Y, Hayaishi O (2007) Prostaglandins and adenosine in the regulation of sleep and wakefulness. Curr Opin Pharmacol 7, 33-38.

[110] Pan WJ, Osmanović SS, Shefner SA (1995) Characterization of the adenosine A1 receptor-activated potassium current in rat locus ceruleus neurons. J Pharmacol Exp Ther 273, 537544.

[111] Liu ZW, Gao XB (2007) Adenosine inhibits activity of hypocretin/orexin neurons by the A1 receptor in the lateral hypothalamus: a possible sleep-promoting effect. J Neurophysiol 97, 837-848.

[112] Oishi Y, Huang ZL, Fredholm BB, Urade Y, Hayaishi O (2008) Adenosine in the tuberomammillary nucleus inhibits the histaminergic system via A1 receptors and promotes nonrapid eye movement sleep. Proc Natl Acad Sci U S A 105, 19992-19997.

[113] Huang ZL, Qu WM, Eguchi N, Chen JF, Schwarzschild MA, Fredholm BB, Urade Y, Hayaishi O (2005) Adenosine A2A, but not A1, receptors mediate the arousal effect of caffeine. Nat Neurosci 8, 858-859.

[114] Bjorness TE, Kelly CL, Gao T, Poffenberger V, Greene RW (2009) Control and function of the homeostatic sleep response by adenosine A1 receptors. J Neurosci 29, 1267-1276.

[115] Deurveilher S, Lo H, Murphy JA, Burns J, Semba K (2006) Differential c-Fos immunoreactivity in arousal-promoting cell groups following systemic administration of caffeine in rats. J Comp Neurol 498, 667-689.

[116] Shen H-Y, Li T, Abreu R, Fredholm BB, Boison D, Chen $\mathrm{J}-\mathrm{F}$ (2008) Selective inactivation of adenosine A2A receptors in striatal neurons abolishes motor and arousal effects of caffeine. Soc Neurosci Abst 384, 5.

[117] Lau CE, Falk JL (1994) Tolerance to oral and IP caffeine: locomotor activity and pharmacokinetics. Pharmacol Biochem Behav 48, 337-344.

[118] Cauli O, Pinna A, Valentini V, Morelli M (2003) Subchronic caffeine exposure induces sensitization to caffeine and crosssensitization to amphetamine ipsilateral turning behavior in- 
dependent from dopamine release. Neuropsychopharmacology 28, 1752-1759.

[119] Simola N, Morelli M, Seeman P (2008) Increase of dopamine $\mathrm{D} 2$ (High) receptors in the striatum of rats sensitized to caf- feine motor effects. Synapse 62, 394-697.

[120] Badiani A, Robinson TE (2004) Drug-induced neurobehavioral plasticity: the role of environmental context. Adv Pharmacol 42, 987-990. 